\title{
FILSAFAT PANCASILA DAN FILSAFAT HUKUM SEBAGAI DASAR RULE OF MORAL
}

\author{
Oleh : \\ Dra. Luh Suryatni, M.Si \\ Dosen Tetap Fakultas Hukum Universitas Suryadarma \\ dan Aktif di Lembaga Konsultasi Bantuan Hukum (LKBH) Fakultas Hukum Universitas Suryadarma \\ Email : (luhsuryatni@gmail.com)
}

\begin{abstract}
Abstrak:
Pancasila as the philosophy of life of the Indonesian nation, grow and develop along with the growth and development of the Indonesian nation. The principles contained in Pancasila rooted in the culture and experience of the Indonesian nation, which developed as a result of the nation's efforts in seeking answers to the essential issues concerning the meaning on the nature of things and become a part of Indonesian life. Philosophy of Law adopted will serve as the foundation of philosophical and norms of criticism for the entry into force of the Law and the Rules of the overall processes of the legal life of the community in question, which includes the creation and implementation and enforcement. Philosophy of Law were adopted it was part of the worldview espoused in the communities concerned. It can be said that the Philosophy of Law is the adoption of a view of life in the field of rule of law is derived from rule of morals.
\end{abstract}

Keyword: Pancasila phylosophy, Phylosophy of law, and Rule of morals.

\section{A. PENDAHULUAN}

Perkembangan masyarakat dunia yang semakin cepat secara langsung ataupun tidak langsung mengakibatkan perubahan besar pada berbagai bangsa di dunia. Gelombang besar kekuatan internasional dan transnasional melalui globalisasi telah mengancam, bahkan menguasai eksistensi negara - negara bangsa, termasuk Indonesia. Akibat yang langsung terlihat terjadinya pergeseran nilai-nilai dalam kehidupan kebangsaan karena adanya perbenturan kepentingan antara nasionalisme dan internasionalisme.

Prinsip-prinsip dasar yang telah ditentukan oleh peletak dasar (the founding fathers) negara Indonesia yang kemudian diabstraksikan menjadi suatu prinsip dasar filsafat bernegara, itulah Pancasila. Dengan pemahaman demikian, maka Pancasila sebagai filsafat hidup bangsa Indonesia saat ini mengalami ancaman dengan munculnya nilai-nilai baru dari luar dan pergeseran nilai-nilai yang terjadi. 
Secara ilmiah harus disadari bahwa suatu masyarakat, suatu bangsa, senantiasa memiliki suatu pandangan hidup atau filsafat hidup masingmasing, yang berbeda dengan bangsa lain di dunia. Ini yang disebut sebagal local. genius (kecerdasan/kreativitas lokal) dan sekaligus sebagai local wisdom (kearifan lokal) bangsa. Dengan demikian, bangsa Indonesia tidak mungkin memiliki kesamaan pandangan hidup dan filsafat hidup dengan bangsa lain. Ketika para pendiri negara Indonesia menyiapkan berdirinya negara Indonesia merdeka, mereka sadar sepenuhnya untuk menjawab suatu pertanyaan yang fundamental "di atas dasar apakah negara Indonesia merdeka ini didirikan?" (Soekarno, 1945).

Jawaban atas pertanyaan mendasar ini akan selalu menjadi dasar dan tolak ukur utama bangsa ini mengIndonesia dengan kata lain jati diri bangsa akan selalu bertolak ukur pada nilai - nilai pancasila sebagai filsafat bangsa. Pancasila yang terdiri atas lima sila pada hakekatnya merupakan sistem filsafat. Pemahaman demikian memerlukan pengkajian lebih lanjut menyangkut aspek ontologi, epistemologi, dan aksiologi dari kelima sila Pancasila.

Secara Ontologis kajian Pancasila sebagai filsafat dimaksudkan sebagai upaya untuk mengetahui hakikat dasar dari sila-sila Pancasila. Menurut Notonagoro hakikat dasar ontolagis Pancasila adalah manusia. Mengapa? karena manusia merupakan subjek hukum pokok dari sila-sila Pancasila.

Hal ini dapat dijelaskan bahwa yang berketuhanan Yang Maha Esa, berkemanusian yang adil dan beradab, berkesatuan Indonesia, berkerakyatan yang dipimpin oleh hikmah kebijaksanaan dalam permusyawaratan / perwakilan, serta berkeadilan sosial bagi seluruh rakyat Indonesia pada hakikatnya adalah manusia (Kaelan, 2005).

Dengan demikian, secara ontologis hakikat dasar keberadaan dari sila-sila Pancasila adalah manusia. Untuk hal ini, Notonagoro lebih lanjut mengemukakan hahwa manusia sebagai pendukung pokok sila-sila Pancasila secara ontologis memiliki hal-hal yang mutlak, yaitu terdiri atas susunan kodrat, raga dan jiwa, serta jasmani dan rohani. Selain itu, sebagai makhluk individu dan sosial, serta kedudukan kodrat manusia sebagai makhluk pribadi dan sebagai makhluk Tuhan Yang Maha Esa.

OIeh karena itu, secara hierarkis sila pertama Ketuhanan Yang Maha Esa mendasari dan menjiwai keempat silasila Pancasila. Selanjutnya, Pancasila sebagai dasar filsafat negara Republik Indonesia memiliki susunan lima sila yang merupakan suatu persatuan dan kesatuan, serta mempunyai sifat dasar kesatuan yang mutlak, yaitu berupa sifat kodrat monodualis, sebagai makhluk individu sekaligus juga sebagai makhluk sosial. Di samping itu, kedudukannya sebagai makhluk pribadi yang berdiri sendiri, sekaligus sebagai makhluk Tuhan.

Konsekuensinya, segala aspek dalam penyelenggaraan negara dijiwai oleh nilai-nilai Pancasila yang merupakan suatu kesatuan yang utuh dan memiliki sifat dasar yang mutlak berupa sifat kodrat manusia yang 
monodualis tersebut. Kemudian, seluruh nilai - nilai Pancasila tersebut menjadi dasar raga dan jiwa bagi bangsa Indonesia. Hal ini berarti bahwa dalam setiap aspek penyelenggaraan negara harus dijabarkan dan bersumberkan pada nilai-nilai Pancasila, seperti bentuk negara, sifat negara, tujuan negara, tugas / kewajiban negara dan warga negara, sistem hukum negara, moral negara, serta segala aspek penyelenggaraan negara lainnya.

Kajian Epistemologi filsafat Pancasila dimaksudkan sebagai upaya untuk mencari hakikat Pancasila sebagai suatu sistem pengetahuan. Hal ini dimungkinkan karena epistemologi merupakan bidang filsafat yang membahas hakikat ilmu pengetahuan (ilmu tentang ilmu). Kajian epistemologi Pancasila tidak dapat dipisahkan dengan dasar ontologisnya. Oleh karena itu, dasar epistemologis Pancasila sangat berkaitan erat dengan konsep dasarnya tentang hakikat manusia.

Epistemologi Pancasila sebagai suatu objek kajian pengetahuan pada hakikatnya meliputi masalah sumber dan susunan pengetahuan Pancasila. Adapun tentang sumber pengetahuan Pancasila, sebagaimana telah dipahami bersama, adalah nilai - nilai yang ada pada bangsa Indonesia itu sendiri. Merujuk pada pemikiran filsafat Aristoteles, bahwa nilai-nilai tersebut sebagai kausa materialis Pancasila. Selanjutnya, susunan Pancasila sebagai suatu sistem pengetahuan maka Pancasila memiliki susunan yang bersifat formal logis, baik dalam arti susunan sila-sila Pancasila maupun isi arti dari dalil sila-sila Pancasila itu. Susunan kesatuan sila-sila Pancasila adalah bersifat hierarkis dan berbentuk piramidal, yaitu:

a. Sila pertama Pancasila mendasari dan menjiwai keempat sila Iainnya

b. Sila kedua didasari sila pertama serta mendasari dan menjiwai sila ketiga, keempat, dan kelima

c. Sila ketiga didasari dan dijiwai sila pertama dan kedua, serta mendasari dan menjiwai sila keempat dan kelima

d. Sila keempat didasari dan dijiwai sila pertama, kedua, dan ketiga, serta mendasari dan menjiwai sila kelima, serta

e. Sila kelima didasari dan dijiwai sila pertarna, kedua, ketiga, dan keempat.

Demikian, susunan Pancasila memiliki sistem logis, baik yang menyangkut kualitas maupun kuantitasnya. Dasar-dasar rasional logis Pancasila juga menyangkut kualitas ataupun kuantitasnya. Selain itu, dasar-dasar rasional logis Pancasila juga menyangkut isi arti sila - sila Pancasila tersebut. Sila Ketuhanan Yang Maha Esa memberi landasan kebenaran pengetahuan manusia bersurnber pada intuisi. Kedudukan dan kodrat manusia pada hakikatnya adalah sebagai makhluk Tuhan Yang Maha Esa.

Karena itu, sesuai dengan sila pertama Pancasila, Episternologi Pancasila juga mengakui kebenaran wahyu yang bersifat mutlak. Hal ini sebagai tingkat kebenaran yang tertinggi. Disamping itu, kebenaran dan pengetahuan manusia merupakan suatu sintesis harmonis di antara potensi - potensi 
kejiwaan manusia, yaitu akal, rasa, dan kehendak manusia untuk mendapatkan kebenaran yang tertinggi. Selain itu, dalam sila ketiga, keempat, dan kelima, epistemologi Pancasila rnengakui kebenaran konsensus terutama dalam kaitannya dengan hakikat sifat kodrat manusia sebagai makhluk individu dan makhluk sosial sebagai suatu paham epistemologi, Pancasila memandang bahwa ilmu pengetahuan pada hakikatnya tidak bebas nilai karena harus diletakkan pada kerangka moralitas kodrat manusia serta moralitas religius dalam upaya untuk mendapatkan suatu tingkatan pengetahuan dalam hidup manusia. Itu sebabnya Pancasila secara epistemologis harus menjadi dasar moralitas bangsa dalam membangun perkembangan sains dan teknologi dewasa ini.

Aksiologi Pancasila mengandung arti bahwa kita membahas tentang filsafat nilai Pancasila. Istilah nilai dalam kajian filsafat dipakai untuk merujuk pada ungkapan abstrak yang dapat juga diartikan sebagai "keberhargaan" (worth) atau "kebaikan" (goodnes), dan kata kerja yang artinya sesuatu tindakan kejiwaan tertentu dalam menilai atau melakukan penilaian. Secara aksiologis, Bangsa Indonesia merupakan pendukung nilai-nilai Pancasila, karena Bangsa Indonesia yang berketuhanan, yang berkemanusiaan, yang berpersatuan, yang berkerakyatan, dan yang berkeadilan sosial.

Sebagai pendukung nilai, bangsa Indonesia yang menghargai, mengakui, serta menerima Pancasila sebagai sesuatu yang bernilai.
Pengakuan, penghargaan, dan penerimaan Pancasila sebagai sesuatu yang bemilai itu akan tampak menggejala dalam sikap, tingkah laku, dan perbuatan bangsa Indonesia. Kalau pengakuan, penerimaan, atau penghargaan itu telah menggejala dalam sikap, tingkah laku, serta perbuatan manusia dan bangsa Indonesia, maka bangsa Indonesia dalam hal ini sekaligus adalah pengembannya dalam sikap, tingkah laku, dan perbuatan manusia Indonesia.

Filsafat hukum adalah pendirian atau penghayatan kefilsafatan (yang paling fundamental) yang dianut orang atau masyarakat atau negara tentang hakikat, ciri-ciri hakiki serta landasan berlakunya hukum. Filsafat Hukum yang dianut akan berperan sebagai landasan kefilsafatan dan norma kritik bagi berlakunya Tata Hukum serta keseluruhan proses-proses kehidupan hukum di dalam masyarakat bersangkutan, yang meliputi pembentukan dan penerapan serta penegakan hukum.

Filsafat Hukum yang dianut itu adalah bagian dari pandangan hidup yang dianut dalam masyarakat bersangkutan. Dapat dikatakan, bahwa Filsafat Hukum adalah penerapan pandangan hidup dalam bidang hukum. Di dalam hukum yang terjadi adalah proses penilaian. Yang dinilai adalah perilaku manusia di dalam pergaulan hidup manusia, perilaku di dalam jaringan berbagai hubungan sosial. Yang melakukan penilaian adalah manusia juga. Karena itu, pada akhirnya yang menentukan isi peraturan hukum, yakni ketentuan tentang keharusan 
cara berperilaku tertentu, adalah penghayatan atau pandangan manusia tentang kedudukan dari tiap manusia di dalam pergaulan hidup manusia dan di dalam alam semesta dalam interaksi dengan dan antara kedua faktor di atas. Pandangan atau penghayatan manusia tentang tempat dirinya dalam rangka keseluruhan itu disebut pandangan hidup. Dengan demikian, maka tiap Tata Hukum akan mencerminkan atau diwarnai oleh pandangan hidup tertentu atau pandangan tentang hakikat manusia yang dianut atau hidup dalam masyarakat yang dari dalamnya Tata Hukum itu tumbuh dan berlaku sebagai hukum.

Pandangan hidup tersebut berpangkal tolak dari landasan kefilsafatan serta ukuran bagi norma kritik yang rnendasari atau menjiwai tata hukum. Karena itu, pandangan hidup yang dianut akan memberikan koherensi (kesatupaduan) dan pengarahan pada keseluruhan proses-proses sosial penormaan (pengkaidahan) peraturanperaturan hukum beserta dengan proses-proses penerapannya dalam kehidupan bermasyarakat. Oleh koherensi dan pengarahan itu maka keseluruhan peraturan-peraturan hukum dan institusi - institusi (pranata - pranata) hukum yang berlaku dan hidup dalam masyarakat dalam proses kehidupannya akan mewujudkan diri menjadi suatu kesatuan berstruktur, bersistem dan dinamis.

Jadi, Tata Hukum adalah hasil perpaduan dinamis antara pandangan hidup yang dianut dan kenyataan lingkungan hidup manusia yang dipadatkan dalam keseluruhan asas- asas hukum, kaidah-kaidah hukum dan pranata-pranata hukum yang tersusun dalam suatu struktur yang bersistem. Juga Filsafat Hukum yang merumuskan landasan kefilsafatan dan norma kritik bagi Tata Hukum yang berlaku akan diwarnai oleh Pandangan Hidup yang dianutnya.

Berdasarkan urian tersebut diatas yang menjadi masalah dalam tulisan ini adalah apakah Filsafat Pancasila dan Filsafat Hukum dapat dijadikan dasar dalam penerapan Rule of morals?

\section{B. PEMBAHASAN}

Pancasila sebagai falsafah hidup bangsa Indonesia, tumbuh dan berkembang bersamaan dengan tumbuh dan berkembangnya bangsa Indonesia. Prinsip-prinsip yang terdapat dalam Pancasila bersumber pada budaya dan pengalaman bangsa Indonesia, yang berkembang akibat dari upaya bangsa dalam mencari jawaban atas persoalan-persoalan esensial yang menyangkut makna atas hakikat sesuatu dan menjadi bagian dari kehidupan bangsa Indonesia, yang meliputi antara lain:

a. alam semesta, seperti bagaimana alam semesta ini terbentuk, bagaimana hubungan antara unsurunsur yang terdapat dalam alam semesta, bagaimana hubungan antara micro-cosmos dan macrocosmos, siapa pencipta alam semesta dan sebagainya;

b. manusia dan kehidupannya; siapa sebenarnya manusia itu, darimana asalnya dan kemana kembalinya, bagaimana hubungan manusia dengan manusia lain, dengan 
masyarakat, dan dengan Pencipta manusia dan sebagainya;

c. nilai-nilai yang kemudian diangkat menjadi norma-norma yang mengatur kehidupan; seperti nilainilai tentang baik dan buruk, benar dan salah, berguna dan tidak berguna dan sebagainya. (Subandi,2006)

Pancasila merupakan falsafah hidup bangsa Indonesia mengandung nilainilai dasar yang dijunjung tinggi oleh bangsa Indonesia, bahkan oleh bangsa-bangsa yang beradab. Karena pandangan hidup bangsa Indonesia telah dirumuskan secara padat dalam bentuk kesatuan rangkaian lima sila yang dinamakan Pancasila. Dengan sengaja Pancasila ditempatkan dalam pembukaan Undang-Undang Dasar 1945 sebagai landasan kefilsafatan yang mendasari dan menjiwai penyusunan ketentuan-ketentuan yang tercantum dalam Undang-Undang Dasar 1945 itu.

Dengan demikian, maka Pancasila melandasi dan (seharusnya) menjiwai kehidupan kenegaraan di Indonesia, termasuk kegiatan menentukan dan melaksanakan politik hukumnya. Penyusunan dan penerapan Tata Hukum di Indonesia sejak berlakunya Undang-Undang Dasar 1945 itu tadi harus dilandasi dan dijiwai oleh Pancasila. Dimana Pandangan Hidup Pancasila berpangkal pada keyakinan bahwa alam semesta dengan segala hal yang ada di dalamnya sebagai suatu keseluruhan yang terjalin secara harmonis diciptakan oleh Tuhan Yang Maha Esa. Juga manusia diciptakan oleh Tuhan Yang Maha Esa. Manusia berasal dari Tuhan dan tujuan akhir dari kehidupannya adalah untuk kembali kepada sumber asalnya. Bertaqwa dan mengabdi Tuhan menjadi kewajiban manusia yang wajar.

Manusia diciptakan Tuhan dengan kodrat sebagai mahluk bermasyarakat. Artinya, kehadiran manusia di dunia dikodratkan dalam kebersamaan dengan sesamanya. Dalam kebersamaannya itu, tiap manusia memiliki kepribadian unik yang membedakan yang satu dari yang lain. Keseluruhan pribadi-pribadi dengan keunikannya masing-masing mewujudkan satu kesatuan, yakni kemanusiaan. Dalam masing-masing pribadi yang unik itu terdapat atau terjelma kemanusiaan.

Kehadiran manusia dalam kebersamaannya memperlihatkan kodrat adanya kesatuan atau kesamaan, yakni kemanusiaan dalam pribadi-pribadi yang unik, dan berbeda. Jadi, kesatuan dalam perbedaan. Sebaliknya, kebersamaan itu memperlihatkan kodrat kepribadian yang unik, yakni perbedaan-perbedaan, di dalam kesatuan kemanusiaan. Jadi, perbedaan dalam kesatuan. Dalam Lambang Negara Republik Indonesia, kodrat itu dirumuskan dalam seloka: "Bhinneka Tunggal Ika".

Dilihat dari jalan pikiran tersebut, Bhinneka Tunggal Ika itu merumuskan asas pertama atau titik tolak (postulat) dalam menetapkan pendirian tentang kedudukan tiap manusia di dalam masyarakat. Manusia adalah subyek yang memiliki kepribadian unik sebagai kodratnya. Kodrat berkepribadian ini tidak dapat disangkal tanpa meniadakan juga 
kodrat kemanusiaannya. Setiap manusia untuk dapat menjadi manusia harus mengakui dan menerima adanya kepribadian itu, termasuk kepribadian manusiamanusia lain. Hal ini berlaku juga bagi masyarakat. Artinya, untuk tetap mempertahankan eksistensinya sebagai masyarakat manusia yang berkemanusiaan, maka masyarakat harus mengakui dan memelihara serta melindungi kepribadian masingmasing anggotanya, yakni manusiamanusia, melalui siapa kemanusiaan diwujudkan.

Maksudnya, di dalam diri tiap manusia, masyarakat mewujudkan kemanusiaan. Sebaliknya, hal itu tidak berarti bahwa masing-masing individu manusialah yang terpenting, dan karena itu kepentingan tiap manusia masing-masing secara bersendiri harus didahulukan dari masyarakat. Sebab, terbawa oleh kodrat kehadiran manusia dalam kebersamaan dengan sesamanya, manusia hanya dapat mewujudkan kemanusiaannya dalam masyarakat yang di dalamnya tiap manusia menjadi anggotanya. Terbawa oleh struktur kehadiran manusia dalam kebersamaan dengan sesamanya itu, maka sifat hubungan antar-manusia dan antara tiap manusia dengan masyarakat dilandasi dan dijiwai oleh cinta-kasih.

Sifat cinta-kasih yang menjiwai hubungan manusiawi itu terbawa oleh kodrat kebersamaannya, juga pada akhirnya bersumber pada Sang Maha Pencipta, yakni Tuhan Yang Maha Esa. Sifat hubungan manusiawi yang demikian itu dinamakan juga kekeluargaan. Pandangan Hidup
Pancasila dapat juga disebut Pandangan Hidup Kekeluargaan.

Asas Kekeluargaan adalah rumusan asas hidup yang didasarkan atas pemikiran konkret. Dasar pemikiran konkret ini menyatakan bahwa tiada manusia yang kehadiran dan kehidupannya terlepas dari kaitan kebersamaan dengan manusiamanusia lain dalam kesatuan masyarakat. Dalam asas itu tercakup juga kesadaran dan pengakuan bahwa hidup manusia tergantung pada lingkungannya seperti alam, sesama manusia dan pola perilaku tertentu yang sudah diinstitusionalisasikan (adat istiadat dan kebiasaan), juga tergantung pada sesuatu yang ada di atas segala-galanya (Tuhan Yang Maha Esa, Dunia Supranatural, Dunia Transenden).

Karena itu, kebahagiaan pribadi dan upaya untuk mewujudkannya tidak dapat diisolasi dari kebahagiaan manusia-manusia lain yang bersamasama mewujudkan kebahagiaan bersama; serta upaya pribadi dan bersama itu tidak diisolasi dari ketergantungan kepada Tuhan Yang Maha Esa; kebahagiaan pribadi dan kebahagiaan masyarakat sebagai satu keseluruhan adalah berintegrasi. Dimana nilai-nilai yang sedang hidup berkembang dalam masyarakat masih memerlukan kristalisasi. Meskipun dilihat dari segi hukum norma-norma hukum mempunyai kekuatan mengikat yang lebih tinggi dan sanksi yang lebih kuat (dapat memaksakan pelaksanaannya), dilihat dari segi kemanfaatan, norma hukum dan bukan norma hukum mempunayai pengaruh timbal-balik, saling mengisi Pengaruh timbal-balik ini, baik dalam 
pembentukan norma-norma hukum (penyusunan hukum positif) maupun dalam penerapannya oleh unsur-unsur penegak hukum (alat-alat dan badanbadan peradilan). Namun, demi kemanfaatan dan demi kepastian hukum, pada umumnya dalam pelaksanaannya norma-norma hukum mempunyai peranan yang lebih menentukan (Santiajai Pancasila, 1991)

Reformasi socio-moral yang berdasarkan Ideologi Pancasila berarti akan menciptakan a) sistem kelembagaan ; b) sistem tanggap nilai; c) sistem norma yang ideal, di mana kelembagaan, tanggap nilai dan sistem norma yang ideal tersebut dengan dunia yang semakin maju dan berkembang (moderen) ditandai dengan kemaju-an komunikasi, teknologi dan sains penuh dengan tantangan dari luar dan atau dari dalam sendiri yang mendengar informasi dari luar, tidak mungkin kedap terhadap perubahan-perubahan tersebut. Disini akan terjadi proses akulturisasi. Ini berarti suatu Ideologi apapun namanya termasuk Ideologi Pancasila, "terbuka" terhadap suatu perubahan yang datangnya dari luar, walaupun nilai-nilai dasar yang terkandung di dalamnya tidak berubah.

Sebagai hasil dari reformasi socio moral tercipta suatu peradaban Pancasila dalam masyarakat berdasarkan Pancasila. Masyarakat yang berdasarkan Pancasila ini mempunyai ciri-ciri sebagai berikut: Bhinneka Dalam Gatra; Tunggal Dalam Karsa; Ika Dalam Citra (Widjaja,1991). Jadi, reformasi socio moral perlu adanya tujuan, usaha (laku) dan landasan, yang merupakan formulasi sadar akan kehendak. Apabila telah disadari tujuan, usaha dan sadar akan landasan, sikapnya terhadap tantangan akan jelas. Konsep teoritiknya merupakan konsep tingkah laku di mana bentuk prikehidupan, socio budaya adalah penjelmaan proses nilai universal dalam individu dan masyarakat.

Nilai dasar sebagai nilai kriteria merupakan respons yang bersifat fleksibel dalam perwujudan sistem kelembagaan, kritis dalam realitas (sistem tanggap nilai) dan konsisten dalam nilai (norma ideal). Peradaban Pancasila merupakan buah dari reformasi socio moral, harus rnempunyai wujud realita, harus mempunyai suatu citra terhadap realita dan harus merupakan realisasi daripada citra. Karena, pandangan hidup bangsa Indonesia sejak dari dahulu hingga kini adalah Pancasila. Dalam dinamika proses-proses kemasyarakatan, Pancasila diwujudkan dalam berbagai bidang kehidupan, juga pada bidang kehidupan hukum.

Penerapan atau realisasi Pancasila pada bidang kehidupan hukum itu menumbuhkan ketentuan-ket'entuan hukum yang dijiwai atau diwarnai oleh Pancasila. Keseluruhan Tata Hukum sebagai suatu sistem aturan hukum positif merupakan penjabaran atau penerapan Pancasila pada bidang hukum, dapat disebut Hukum Pancasila. Hukum Pancasila sebagai hukum positif tumbuh dari dalam dan/atau dibuat oleh masyarakat Indonesia untuk mengatur dan mewujudkan ketertiban yang adil dalam kehidupan kemasyarakatan di 
Indonesia. Hukum Pancasila dapat juga disebut Hukum (Nasional) Indonesia.

Proses terbentuknya peraturanperatuan hukum positif itu dapat terjadi melalui tindakan nyata para warga masyarakat dalam menjalani kehidupan sehari-hari, dari perulangan perilaku yang sama tiap kali terjadi situasi kemasyarakatan yang sama. Dalam hal ini, maka terbentuk hukum tidak tertulis (hukum kebiasaan dan hukum adat). Proses terbentuknya peraturan hukum itu dapat juga terjadi secara disengaja melalui keputusan-keputusan para pejabat, yurisprudensi dan perundangundangan. Produk dari keseluruhan proses pembentukan peraturan hukum positif itu mewujudkan Tata Hukum.

Hukum Adat yang tumbuh dari dan di dalam lingkungan-lingkungan masyarakat Adat Indonesia, juga merupakan penjelmaan Pancasila pada bidang hukum pada tahap perkembangan tertentu. Hukum Adat adalah bagian dari Hukum (Nasional) Indonesia. Tentu saja, dalam proses dinamika perkembangan masyarakat dapat terjadi adanya peraturanperaturan hukum (adat) positif dan institusi-institusi hukum (adat) yang sudah tidak sesuai dan tidak memenuhi lagi kebutuhan konkret masyarakat dan para warga masyarakatnya (Soepomo, 1963).

Hal ini dapat juga terjadi pada produk perundang-undangan dan keputusankeputusan pejabat lainnya. Dalam keadaan demikian, maka dipaksakannya penerapan peraturanperaturan dan institusi - institusi hukum itu akan tidak lagi merupakan penjelmaan Pancasila dalam situasi konkret. Adalah bijaksana jika peraturan-peraturan dan institusiinstitusi itu diubah dan disesuaikan pada kenyataan riil. Sebab arti dan makna konkret suatu asas (nilai, kaidah) selalu ditentukan oleh kenyataan yang riil yang di dalamnya asas itu hendak di realisasikan (kontekstual dan karena itu: historisch bepaald, historically determined). Yang penting adalah bahwa segala sesuatu dilaksanakan melalui prosedurprosedur berdasarkan hukum serta dijiwai oleh Pancasila, sebagai landasan kefilsafatan dan norma kritik bagi Tata Hukum Indonesia.

Pada bagian ini akan dibicarakan gagasan atau cita-hukum (the idea of law, rechtsidee) dalam alam pikiran berdasarkan Pancasila. Secara umum, yang dimakud dengan cita-hukum adalah persepsi tentang apakah hukum itu dan apa makna hukum bagi seseorang atau suatu masyarakat. (Arief Sidharta, 2015) Hukum timbul dari rasa wajib yang tertanam dalam jiwa manusia, yakni dalam akalbudi dan budi-nurani manusia, yang mengharuskan manusia bersikap dan berperilaku dengan cara tertentu terhadap dan berkenaan dengan adanya manusia (manusia-manusia) lain, untuk mewujudkan ketertiban dan keteraturan dalam masyarakat, sedemikian rupa sehingga martabat dan kodrat manusia tidak tertindas.

Keharusan itu menimbulkan hak untuk menuntut agar apa yang diharuskan dilaksanakan; jadi, adanya kewajiban itu sekaligus menimbulkan hak. Kewajiban bersikap dan berperilaku tertentu terhadap orang lain itu dirasakan sebagai apa yang 
sudah sepantasnya dan seadilnya menjadi hak orang lain itu. Manusia merasa berwajib dan dituntut untuk memberikan kepada orang lain apa yang menjadi bagiannya atau haknya. Kewajiban dan hak itu timbul karena dan di dalam hubungan antarmanusia; jadi, adanya hak dan kewajiban itu mengatur hubungan antar-manusia. Hak dan kewajiban itu selalu berarti dan hanya dapat dipahami sebagai hak dan kewajiban terhadap manusia atau manusiamanusia lain. Jadi, hak dan kewajiban itu menunjuk atau mengungkapkan hubungan antar-manusia. Karena itu, hukum pada hakikatnya adalah hubungan antar-manusia dalam dinamika kehidupan bermasyarakat, untuk menjaga ketertiban sosial berdasarkan asas budaya.

Hukum yang mewujudkan diri sebagai proses-proses sosial pengaturan atau pengkaidahan cara berperilaku. Proses sosial itu menghasilkan kaidah-kaidah hukum. Hukum adalah pengaturan perilaku manusia dalam menyelenggarakan hubungan antar-sesamanya di dalam masyarakat. Sebagai pengaturan perilaku, selain untuk mewujudkan ketertiban dan keteraturan dalam masyarakat, hukum juga dimaksudkan untuk mewujudkan asas keadilan.

Karena itu, hukum diarahkan untuk memberikan kepada setiap orang apa yang menjadi bagiannya sesuai dengan jasa atau apa yang telah diberikannya; memberikan perlakuan yang sama menurut proporsinya, memberikan imbalan sesuai dengan kecakapan dan jasanya terhadap masyarakat, dan memberikan hukuman sesuai dengan kesalahannya. Kesemuanya ini adalah akibat yang timbul dari kenyataan bahwa keberadaan manusia dikodratkan berstruktur ada-bersamadengan-sesamanya (ada dalam kebersamaan dengan sesamanya). Karena manusia dikodratkan ada bersama dengan sesamanya dalam masyarakat, maka manusia tidak dapat mengelakkan diri dari keberadaan dalam pergaulan dengan sesamanya. Justru karena itu, maka ketertiban dan keteraturan dalam masyarakat yang dikehendaki (yang manusiawi) adalah yang tidak kaku, yang semata-mata hanya berdasarkan perhitungan untung-rugi saja, yang (dapat) mewujudkan ketertiban yang menekan perkembangan kemanusiaan.

Yang dikehendaki adalah ketertiban dan keteraturan yang bersuasana ketenteraman batin, kesenangan bergaul di antara sesamanya, keramahan dan kesejahteraan memungkinkan terselenggaranya interaksi antar-manusia sejati. Karena itu, hukum yang dijiwai oleh Pancasila adalah hukum yang berasaskan semangat kerukunan, juga hukum secara langsung diarahkan untuk mewujudkan keadilan sosial yang memberikan kepada masyarakat sebagai kesatuan dan masing-masing warga masyarakat kesejahteraan (material dan spiritual) yang merata dalam keseimbangan dan proporsional.

Terpaut pada asas kerukunan adalah asas kepatutan. Asas ini juga adalah asas tentang cara menyelenggarakan hubungan antar-warga masyarakat yang di dalamnya para warga 
masyarakat diharapkan untuk berperilaku dalam kepantasan yang sesuai dengan kenyataan-kenyataan sosial. Juga dalam melaksanakan hak dan kewajiban yang sah menurut hukum, para warga masyarakat diharapkan untuk memperhatikan kepantasan, yakni dari para warga masyarakat diharapkan berperilaku sedemikian rupa hingga tidak merendahkan martabatnya sendiri dan atau orang lain. Sifat lain yang memberikan ciri pada Hukum Pancasila adalah asas keselarasan.

Asas ini menghendaki terselenggaranya harmoni dalam kehidupan bermasyarakat. Berdasarkan asas ini, maka penyelesaian masalah-masalah konkret, selain harus didasarkan pada pertimbangan kebenaran dan kaidahkaidah hukum yang berlaku, juga harus dapat diakomodasikan pada proses-proses kemasyarakatan sebagai keseluruhan yang utuh dengan mempertimbangkan perasaanperasaan yang sungguh-sungguh hidup dalarn masyarakat.

Dimana para warga masyarakat dan pelaksana hukum diharapkan kepatutan dalam melaksanakan hak dan kewajibannya, sedemikian sehingga kerukunan dan kesejahteraan bermasyarakat dapat dipertahankan dan dikembangkan. Asas kerukunan, asas kepatutan dan asas keselarasan sebagai ciri-ciri khas dari Hukum Pancasila dapat dicakup dengan satu istilah, yakni sifat kekeluargaan. Karena itu, dapat dikatakan bahwa Hukum Pancasila adalah hukum bersemangat kekeluargaan. Semangat kekeluargaan menunjuk pada sikap yang berdasarkannya kepribadian setiap warga masyarakat diakui dan dilindungi oleh masyarakat.

Tujuan hidup manusia adalah mewujudkan kebahagiaan. Dalam bahasa filsafat dikatakan, bahwa tujuan hidup manusia itu adalah mewujudkan kehidupan yang sempurna, atau setidak-tidaknya menjalani kehidupan yang sesempurna mungkin sebagai manusia, yakni dengan mengembangkan semua potensipotensi manusiawi yang ada dalam dirinya secara utuh. Tiap manusia akan berupaya untuk mewujudkan tujuan hidupnya masing-masing. Upaya itu dilaksanakan dengan menjalankan perilaku. Hanya dengan perilaku, manusia dapat mewujudkan tujuan hidupnya.

Tetapi, perilaku saja tidak cukup; untuk dapat mewujudkan tujuan hidupnya itu, manusia juga perlu mempergunakan berbagai hal lain yang ada di luar dirinya, misalnya benda mati dan binatang. Karena kodrat kebersamaan dengan sesamanya, maka segala upaya yang dilakukan manusia itu berlangsung dalam hubungan-hubungan kemasyarakatan. Di lain pihak, terbawa oleh kodratnya, manusia tidak dapat dijadikan obyek dan alat oleh sesamanya tanpa meniadakan kemanusiaannya. Karena setiap manusia memerlukan benda-benda dan binatang - binatang itu untuk memenuhi tujuan hidupnya masingmasing, dan tidak ada seorang pun yang mau dijadikan obyek atau alat oleh orang lain, maka di dalam hubungan kemasyarakatan itu dengan sendirinya timbul pengertian hak bahwa setiap manusia sama-sama 
mempunyai hak untuk menggunakan benda-benda dan binatang-binatang itu serta untuk tidak dijadikan obyek atau alat oleh orang lain; dan bersamaan dengan itu timbul pengertian hukum dapat kita pahami, pelaksanaan hak untuk hidup dan mencapai tujuan hidup masirigmasing tidak mungkin terjadi secara wajar bila di dalam masyarakat terdapat kekacauan.

Dengan kata lain, manusia memerlukan terselenggaranya ketertiban dan keteraturan di dalam masyarakat. Karena ketertiban dan keteraturan itu diwujudkan dalam perilaku manusia, maka diperlukan sejumlah peraturan perilaku yang kepatuhannya tidak dapat diserahkan sepenuhnya kepada kemauan bebas setiap manusia. Peraturan-peraturan perilaku yang demikian itu disebut hukum, yang pelaksanaannya harus dapat dipaksakan oleh otoritas publik. Jadi, dapatlah disimpulkan, bahwa salah satu tujuan dari hukum adalah mengatur perilaku manusia di dalam hubungan-hubungan kemasyarakatan, jika perlu dengan paksaan, sehingga terwujud ketertiban dan keteraturan, secara singkat: mewujudkan ketertiban dan keteraturan dalam masyarakat.

Tetapi, ketertiban dan ketenteraman itu bukanlah tujuan akhir dari hukum, melainkan tujuan antara. Sebab, di dalam masyarakat dapat saja, dengan menggunakan kekuatan, dipaksakan suatu ketertiban yang bersifat tiranik, yang menindas nilai-nilai manusiawi. Tujuan lebihjauh dari hukum adalah mewujudkan kedamaian sejati di dalam masyarakat. Kedamaian sejati akan terwujud, bilamana setiap warga masyarakat merasakan ketenteraman dalam batinnya. Para warga masyarakat akan merasa tenteram, bilamana ia yakin bahwa kelangsungan hidup dan pelaksanaan, termasuk hal mempertahankan, haknya tidak tergantung pada kekuatan. Selain dari itu, perasaan tenteram akan ada bilamana para warga masyarakat merasa yakin, bahwa sepanjang tidak melanggar hak dan tidak merugikan orang lain, tanpa perasaan khawatir, secara bebas dapat menjalankan apa yang diyakininya sebagai benar dan secara bebas ia dapat mengembangkan bakatbakat dan kesenangannya serta ia akan selalu mendapat perlakuan secara wajar dan berperikemanusiaan, adil dan beradab, juga ketika ia telah melakukan suatu kesalahan.

Dalam tujuan hukum yang digambarkan tadi, secara implisit, sudah mencakup tujuan lain dari hukum, yakni mewujudkan keadilan. Kelangsungan ketertiban dan kedamaian sangat tergantung pada terlaksananya keadilan. Karena itu, terselenggaranya keadilan adalah sangat esensial dalam mewujudkan hukum. Pengertian keadilan meliputi beberapa aspek. Secara umum dikatakan, bahwa keadilan berarti dengan sukarela secara tetap dan mantap terus menerus memberikan kepada tiap orang apa yang memang sudah menjadi bagiannya atau haknya (lustitia est constans et perpetua voluntas ius suum cuique tribuere).

Berdasarkan rumusan tadi, pengertian keadilan dapat dibedakan dalam beberapa aspek berikut ini. Keadilan Distributif (iustitia distributiva) adalah keadilan yang berupa kewajiban 
pimpinan masyarakat untuk memberikan kepada para warga masyarakat beban sosial, fungsifungsi, balas jasa dan kehormatan secara proporsional (seimbang) dengan kecakapan dan jasa masingmasing. Keadilan Komutatif (iustitia commutativd) adalah kadilan yang berupa kesenilaian antara prestasi dan kontra-prestasi, antara jasa dan balas jasa dalam hubungan-hubungan antarwarga, atau, dilihat dari sudut pemerintah memberikan kepada setiap warga secara sama tanpa menghiraukan perbedaan-perbedaan keadaan pribadi ataupun jasanya. Keadilan Vindikatif (iustitia vindicativd) adalah keadilan yang berupa memberikan ganjaran (hukuman) sesuai dengan kesalahan yang bersangkutan. Keadilan Protektif (iustitia protective) adalah keadilan berupa perlindungan yang diberikan kepada setiap manusia, sehingga tak seorangpun akan mendapat perlakuan sewenang-wenang. (Arief Sidharta, 2015).

Rumusan - rumusan tentang keadilan tadi adalah rumusan yang abstrak. Isi dari rumusan-rumusan tadi akan ditentukan oleh kondisi yang di dalamnya keadilan hendak diwujudkan. Yang pasti adalah, bahwa keadilan menuntut bahwa setiap orang tanpa kecuali berkewajiban untuk bertindak sesuai dengan apa yang diwajibkan kepadanya oleh hukum; pengertian hukum di sini tidak selalu berarti hukum positif. Tujuan hukum untuk mewujudkan ketertiban dan keteraturan, kedamaian, serta keadilan dapat dirumuskan dengan satu istilah, yakni Pengayoman (Perlindungan). Jadi, secara singkat padat, tujuan hukum adalah untuk mengayomi manusia.

Tetapi, mengayomi manusia itu tidaklah hanya melindungi manusia dalam arti pasif, yakni hanya mencegah tindakan sewenang-wenang dan pelanggaran hak saja. Melainkan, juga meliputi pengertian melindungi secara aktif, artinya meliputi upaya untuk menciptakan kondisi dan mendorong manusia untuk selalu memanusiakan diri terus menerus. Jadi, dalam alam pikiran Pancasila, tujuan hukum adalah untuk menciptakan kondisi sosial yang manusiawi sedemikian sehingga memungkinkan proses sosial berlangsung secara wajar, di dalamnya secara adil setiap manusia mendapat kesempatan yang seluasluasnya untuk mengembangkan seluruh potensi kemanusiaannya secara utuh. Termasuk dalam rumusan tadi adalah tujuan hukum untuk memelihara dan mengembangkan budi pekerti kemanusiaan serta cita-cita moral rakyat yang luhur berdasarkan Ketuhanan Yang Maha Esa. Selain dari itu, hukum juga secara langsung melalui peraturan-peraturannya mendorong setiap manusia untuk memanusiakan diri.

Secara umum, dapat dikatakan, bahwa tugas/fungsi hukum adalah mengatur hubungan-hubungan kemasyarakan antar-para warga masyarakat satu sama lain dan antara para warga masyarakat dan masyarakat sebagai keseluruhan (negara), sedemikian rupa sehingga terselenggara ketertiban dan keadilan dalam masyarakat. Jadi, tugas/fungsi hukum pertama-tama adalah untuk 
mengabdi kepada ketertiban dan keadilan. Untuk mewujudkan ketertiban dan keadilan, maka tugas hukum adalah menciptakan keteraturan dan kepastian hukum, yakni kepastian yang diciptakan oleh hukum dan kepastian di dalam hukum itu sendiri. Dalam mewujudkan fungsi ini, maka tugas dari hukum adalah untuk menciptakan, menegakkan, memelihara dan mempertahankan keamanan dan ketertiban yang adil. Ini berarti, bahwa hukum juga berfungsi sebagai sistem mekanisme pengendalian sosial untuk memelihara stabilitas sosial poitik.

Untuk melaksanakan fungsi-fungsi yang dikemukakan tadi, maka tugas hukum adalah melalui peraturanperaturannya mencoba menyelaraskan (mengakomodasikan) kepentingankepentingan para warga masyarakat dalam hubungan antara yang satu dengan yang lainnya, serta antara kepentingan warga masyarakat dan masyarakat. Tercakup dalam pengertian tugas hukum itu tadi adalah tugas untuk mengatur kehidupan ekonomi masyarakat sedemikian rupa sehingga setiap warga masyarakat akan mampu secara wajar memenuhi segala kebutuhannya. Jadi, hukum juga pada dasarnya bertugas untuk secara adil mendistribusi kekayaan (pendapatan) masyarakat. Dengan perkataan lain, di samping menjaga keamanan, hukum juga harus mencegah terjadinya kepincangan dan ketidak adilan di dalam masyarakat. Secara positif, hukum juga bertugas untuk mewujudkan keadilan sosial. Terwujudnya keadilan sosial akan menimbulkan perasaan tenteram dalam batin para warga masyarakat.
Dengan terpeliharanya perasaan tenteram itu, maka ketertiban akan mempunyai akar yang kuat.

Telah dikemukakan, bahwa tujuan hukum adalah untuk mewujudkan keadilan. Tetapi, keadilan mensyaratkan terselenggaranya ketertiban; tanpa ketertiban, praktis tidak mungkin atau sulit sekali mewujudkan keadilan. Sebaliknya, ketertiban hanya mungkin bertahan lama jika ketertiban berakar pada ketenteraman masyarakat. Karena itu, maka hukum juga bertugas untuk menciptakan peraturan-peraturan tentang prosedur proses - proses pengaturan (pengkaidahan, penormaan) perilaku dan cara - cara melaksanakan serta mempertahankan peraturan-peraturan hukum, yang selain efektif juga harus memenuhi rasa keadilan. Dalam kondisi masyarakat yang sedang berada dalam keadaan stabil, maka tugas fungsi hukum adalah hanya memelihara dan mempertahankan keamanan, ketertiban dan keteraturan. Tetapi, dalam masyarakat yang sedang mengalami perubahan-perubahan dan sedang melaksanakan pembangunan, maka tugas / fungsi hukum memelihara keamanan dan ketertiban saja tidak cukup, apalagi dalam masa perubahan perubahan kemasyarakatan dan pembangunan pada masa kini.

Perubahan kemasyarakatan adalah proses-proses perubahan dalam tata nilai yang menjiwai masyarakat. Perubahan tata nilai itu meliputi juga perubahan - perubahan dalam sikap dan pola perilaku. Sebelum perubahan itu mengendap dan menjadi mantap, maka terjadi situasi yang di dalamnya 
di samping tata nilai yang baru, masih tetap berlaku tata nilai yang lama yang jalin menjalin secara kabur. Tata nilai itu sendiri adalah hasil dari pengalaman interaksi antar-warga masyarakat dalam proses kehidupan bermasyarakat.

Tetapi, sekali tata nilai terbentuk dan memperoleh kemantapan, maka ia akan mempengaruhi dan membentuk sikap serta pola perilaku para warga masyarakat. Sedangkan tata hukum mencerminkan tata nilai yang berlaku. Dengan demikian terlihat bahwa antara tata nilai, hukum dan perubahan kemasyarakatan terdapat hubungan yang erat. Bilamana dalam masyarakat terjadi perubahan dalam tata nilai dan sikap serta pola perilaku para warganya, maka hukum bertugas untuk memberikan bentuk hukum melalui perubahan dan/atau penciptaan peraturan-peraturan hukum baru pada perubahanperubahan yang sudah terjadi. Hal ini perlu untuk dapat tetap memelihara dan mempertahankan ketertiban dan kepastian (hukum) dalam masyarakat.

Tetapi perubahan kemasyarakatan yang kini tengah berlangsung, menciptakan masalah-maslah yang sangat majemuk hanya dapat ditanggulangi dengan pembangunan berencana. Perubahan hukum tidak dapat lagi menunggu mengendapnya hasil proses perubahan kemasyarakatan itu. Sebab, perencanaan dan pelaksanaan pembangunan secara langsung dihadapkan pada masalah-masalah majemuk sehubungan dengan berlakunya dua tata-nilai (lama dan baru) pada waktu bersamaan. Sikap dan pola perilaku para warga masyarakat, termasuk sebagian dari pimpinan masyarakat masih belum menguntungkan bagi berhasilnya upaya melaksanakan pembangunan berencana yang diinginkan. Padahal penyelesaian masalah-masalah yang dihadapi masyarakat dan para warganya sudah sangat mendesak, namun penyelesaian itu harus tetap berlangsung dengan cara yang tidak menindas martabat manusia.

Ini berarti, bahwa pelaksanaan pembangunan berencana itu harus tetap berdasarkan hukum. Karena itu, maka hukum selain harus tetap mengatur ketertiban dan memelihara keamanan, juga bertugas untuk membuka jalan dan saluran baru dalam sistem kehidupan bermasyarakat agar segala upaya pembangunan berlangsung dengan lancar tanpa menimbulkan kepincangan dan menimbulkan ketidak adilan dalam masyarakat (jurang yang semakin lebar antara yang miskin dan yang kaya). Jadi, hukum juga berfungsi sebagai prasarana pembangunan. Sebagai prasarana pembangunan, tugas hukum adalah membentuk peraturanperaturan hukum dapat menyalurkan kegiatan masyarakat secara tertib teratur dan membagi pendapatan masyarakat secara merata dan adil.

Sehubungan dengan sikap serta pola perilaku yang masih terpaku pada tata nilai lama, maka hukum bertugas untuk mempercepat proses pendidikan masyarakat kearah sikap serta pola perilaku yang paling sesuai dengan masyarakat yang dicita-citakan. Ini adalah fungsi hukum sebagai prasarana pendidikan. Tujuannya adalah untuk memungkinkan 
terjadinya pembangunan dengan cara yang teratur tanpa menindas martabat kemanusiaan para warga masyarakat. Wilayah Indonesia merupakan sebuah kepulauan yang terdiri dari ribuan pulau besar dan kecil. Bangsa Indonesia terdiri dari berbagai suku yang masing-masing memiliki dan hidup dalam atau dengan adatistiadat, hukum adat dan bahasa sendiri-sendiri.

Kondisi ini, selain dapat menghambat proses pembangunan, juga tidak menguntungkan bagi upaya mewujudkan dan mengembangkan cita-cita persatuan dan kesaruan sebagai satu bangsa yang utuh. Kesadaran nasional adalah juga salah satu dari manifestasi tata nilai. Karena itu, menumbuhkan kesadaran nasional secara nyata berarti mengembangkan nilai-nilai sosialbudaya di dalam masyarakat. Berhubung segala hal yang menyangkut hidup manusia harus selalu dapat dipertanggung-jawabkan secara rasional, maka usaha pengembangan nilai-nilai sosialbudaya pun harus dilaksanakan berdasarkan hukum. Dengan demikian, maka hukum juga bertugas untuk meningkatkan kesadaran hukum nasional sehingga kesadaran nasional itu semakin tebal dan semakin nyata dirasakan dan dihayati oleh seluruh warga negara Republik Indonesia. Jadi hukum juga berfungsi untuk secara aktif mempengaruhi perkembangan tata nilai dan tumbuhnya nilai-nilai sosial budaya yang baru. Ini adalah fungsi sosial budaya dari hukum.

Fungsi hukum sebagai prasarana pendidikan dan fungsi sosial-budaya dari hukum bersama-sama mewujudkan atau berakar dalam fungsi hukum sebagai prasarana dan sarana pengadaban masyarakat (yakni sarana untuk mengadabkan dan meningkatkan taraf keadaban para warga masyarakat).

Fungsi sebagai prasarana pembangunan, prasarana pendidikan sosial dan prasarana pengembangan sosial budaya itu, sudah barang tentu, harus dilaksanakan dengan melakukan penciptaan peraturanperaturan hukum yang baru melalui prosedur yang sah dengan tetap berpijak pada hukum dan tata nilai yang berlaku, namun diorientasikan ke masa depan, segala suatu dengan memperhitungkan kenyataankenyataan sosial lainnya yang relevan untuk pembentukan dan penerapan hukum, untuk mencegah hal tersebut maka diterapkan hukum progresif. Hukum progresif merupakan gagasan yang ingin mencari cara untuk mengatasi keterpurukan hukum di Indonesia secara lebih bermakna. Asumsi dasar hukum progresif bahwa hukum adalah untuk manusia, bukan sebaliknya, hukum bukan merupakan institusi yang absolut dan final, hukum selalu berada dalam proses untuk terus-menerus 'menjadi' (law as process, law in the making).

Hukum progresif memuat kandungan moral yang sangat kuat. Dalam konteks ini hukum tidak dijadikan sebagai teknologi yang tidak bernurani, tetapi sebagai suatu institusi yang bermoral, yaitu berdimensi kemanusiaan. Hukum progresif peka terhadap perubahanperubahan dan terpanggil untuk tampil melindungi rakyat menuju 
hukum yang ideal. Hukum progresif menolak keadaan status quo, ia bebas untuk mencari format, pikiran, asas serta aksi-aksi karena. "hukum untuk manusia". Oleh karena itu arah dan watak hukum yang dibangun harus berada dalam hubungan yang sinergis dengan kekayaan yang dimiliki bangsa Indonesia, atau "back to law and order", kembali pada orde hukum dan ketaatan dalam konteks Indonesia. Artinya bangsa Indonesia harus berani mengangkat "Pancasila" sebagai alternatif dalam membangun "negara berdasarkan hukum" versi Indonesia sehingga dapat menjadi "rule of moral atau "rule of justice" yang bersifat "keIndonesia-an" yang lebih mengedepankan "olah hati nurani" daripada "olah otak", atau lebih mengedepankan komitmen moral.

\section{PENUTUP}

Pandangan hidup bangsa Indonesia sejak dari dahulu hingga kini adalah Pancasila. Dalam dinamika prosesproses kemasyarakatan, Pancasila diwujudkan dalam berbagai bidang kehidupan, juga pada bidang kehidupan hukum. Penerapan atau realisasi Pancasila pada bidang kehidupan hukum itu menumbuhkan ketentuan-ket'entuan hukum yang dijiwai atau diwarnai oleh Pancasila. Keseluruhan Tata Hukum sebagai suatu sistem aturan hukum positif merupakan penjabaran atau penerapan Pancasila pada bidang hukum, dapat disebut Hukum Pancasila.

Hukum Pancasila sebagai hukum positif tumbuh dari dalam dan/atau dibuat oleh masyarakat Indonesia untuk mengatur dan mewujudkan ketertiban yang adil dalam kehidupan kemasyarakatan di Indonesia. Hukum Pancasila dapat juga disebut Hukum (Nasional) Indonesia. Proses terbentuknya peraturan-peratuan hukum positif itu dapat terjadi melalui tindakan nyata para warga masyarakat dalam menjalani kehidupan sehari-hari, dari perulangan perilaku yang sama tiap kali terjadi situasi kemasyarakatan yang sama. Dalam hal ini, maka terbentuk hukum tidak tertulis (hukum kebiasaan dan hukum adat). Proses terbentuknya peraturan hukum itu dapat juga terjadi secara disengaja melalui keputusan-keputusan para pejabat, yurisprudensi dan perundangundangan. Produk dari keseluruhan proses pembentukan peraturan hukum positif itu mewujudkan Tata Hukum.

Dimana para warga masyarakat dan pelaksana hukum diharapkan kepatutan dalam melaksanakan hak dan kewajibannya, sedemikian sehingga kerukunan dan kesejahteraan bermasyarakat dapat dipertahankan dan dikembangkan. Asas kerukunan, asas kepatutan dan asas keselarasan sebagai ciri-ciri khas dari Hukum Pancasila dapat dicakup dengan satu istilah, yakni sifat kekeluargaan. Karena itu, dapat dikatakan bahwa Hukum Pancasila adalah hukum bersemangat kekeluargaan. Semangat kekeluargaan menunjuk pada sikap yang berdasarkannya kepribadian setiap warga masyarakat diakui dan dilindungi oleh masyarakat. Sehingga diperlukannya hukum progresif yang memuat kandungan moral yang sangat kuat. Dalam konteks ini hukum tidak dijadikan sebagai teknologi yang tidak bernurani, tetapi 
sebagai suatu institusi yang bermoral, yaitu berdimensi kemanusiaan berdasarkan nilai moral Pancasila.

\section{DAFTAR PUSTAKA}

Arief Shidharta, B. Filsafat Hukum Pancasila, Makalah pada seminar Empat Pilar Kehidupan Berbangsa dan Bernegara, Jakarta, 2015.

Darmodiharjo, Darji, dkk. Santiaji Pancasila, Penerbit Usaha Nasional, Surabaya, Indonesia, 1991.

Kaelan. Filsafat Pancasila sebagai Filsafat Bangsa Negara Indonesia. Makalah pada Kursus Calon Dosen Pendidikan Kewarganegaraan, Jakarta, 2005.

Soekarno. Lahirnya Pancasila, 1945.

Soepomo. Hubungan Individu dan Masyarakat dalam Hukum Adat, Gita Karya, Djakarta, 1963.

Subandi Al Marsudi. Pancasila dan UUD'45 dalam Paradigma Reformasi, PT Raja Grafindo Persada, Jakarta, 2005. 